\title{
The neozoan Elminius modestus Darwin (Crustacea, Cirripedia): Possible explanations for its successful invasion in European water
}

\author{
J. Harms \\ Forschungszentrum Jülich GmbH, Projektträger BEO, \\ Bereich Meeres- und Polarforschung, Seestrasse 15, D-18119 Rostock, Germany
}

\begin{abstract}
Comparison of data from the literature has provided evidence that eurythermal and euryhaline adaptation of larvae and adults in combination with a long seasonal breeding period, high fecundity and short generation time have given Elminius modestus an advantage over indigenous cirripede species, allowing a rapid spread throughout Europedn waters.
\end{abstract}

\section{INTRODUCTION}

Elminius modestus Darwin, a natural inhabitant of waters around New Zealand and southern Australia, was first recorded in European waters in 1945 on fouling plates in Chichester harbour in West Sussex, England (Bishop, 1947). From there, E. modestus spread rapidly along the English coast and was soon found in France and Holland. It is suggested that this species was introduced by shipping during World War II and also that its further spread was due to shipping and natural drift of larvae.

The spread of $E$. modestus is well documented and has been summarized by Harms \& Anger (1989). Since then, the settling area has extended further to places along the west coast of Ireland (King et al., 1997). No information is available on whether and to what extent $E$. modestus is settling along the coast of the Kattegat. It is now considered to be a permanent member of the fouling communities from the Shetland Islands down to Portugal. The variation of abundances has been documented over 40 years for a rocky shore near Plymouth (Southward, 1991).

Why could E. modestus spread so successfully around Europe? A comparison of available information on E. modestus with the one of the native species, Semibalanus balanoides (L.), on larval and adult survival strategy might provide an answer to this question. This paper is an attempt to summarize the widely spread information about these two species, which are considered to be competitors for settling space in the intertidal zone.

\section{DATA COMPARISON AND DISCUSSION}

\section{Larval development}

The time of larval development is a sensitive period during the life cycle of every species. Developmental success has a major influence on spat fall and therefore on the 


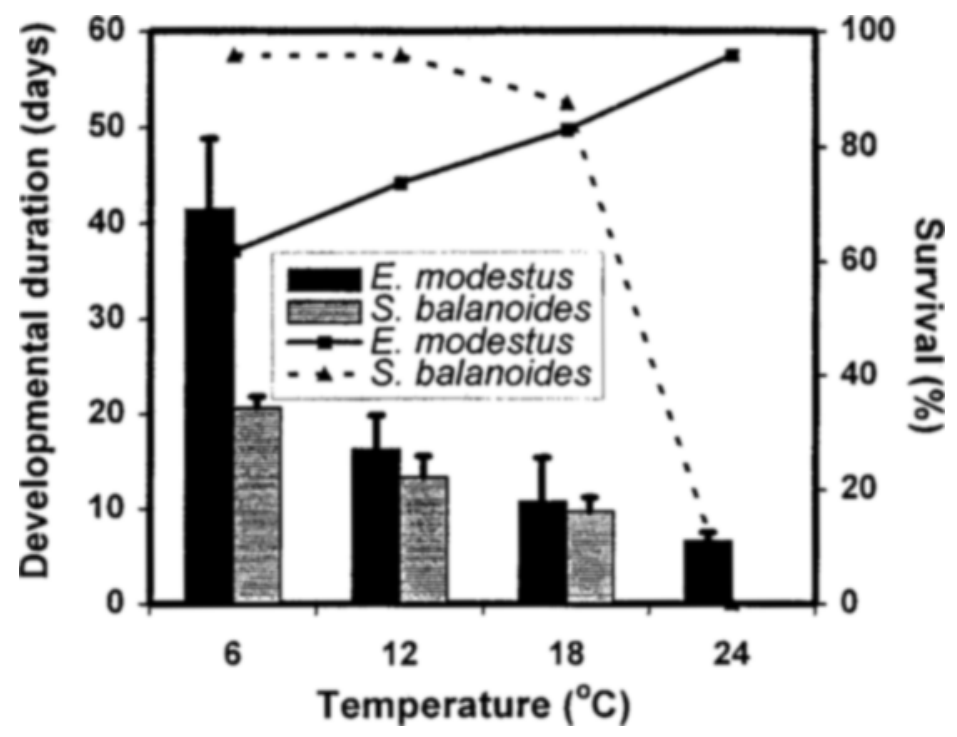

Fig. 1. Temperature influence on larval development up to the cypris stage in Elminius modestus and Semibalanus balanoides (after Harms, 1984). Developmental duration in days (mean value and standard deviation) from hatching to metamorphosis to the cypris stage is shown by columns.

Survival ( $\%$ ) up to the cypris staye is shown by the lines

population size of the next generation. The main environmental factors influencing developmental duration are temperature, salinity and food availability.

The influence of water temperature was examined by Harms (1984) for E. modestus and $S$. balanoides (Fig. 1). S. balanoides is a cold-water species (Hutchins, 1947; Bousfield, 1954), and thus it has its temperature optimum at low temperatures. It was found that none of the larvae of $S$. balanoides developed beyond the second nauplius stage at $24{ }^{\circ} \mathrm{C}$ (Harms, 1984).

The survival of larval stages of $E$. modestus increases with temperature. Unfortunately no temperatures higher than $24^{\circ} \mathrm{C}$ were tested. Because temperatures in the natural environment in New Zealand vary between $4{ }^{\circ} \mathrm{C}$ and $21^{\circ} \mathrm{C}$ (Ritz \& Foster, 1968). $24^{\circ} \mathrm{C}$ seems to be close to the upper limit of tolerance.

The $Q_{10}$ value for the overall developmental duration up to the cypris (see Harms, 1984) was lower in S. balanoides (1.9) than in E. modestus (3.1), but E. modestus larvae develop successfully in a wider temperature range; they are more eurythermal than the larvae of $S$. balanoides.

The influence of salinity on larval development was examined in detail for the European and New Zealand populations of E. modestus (Harms, 1986). Unfortunately no comparable information is available for larvae of $S$. balanoides. Larvae of $E$. modestus showed lowest mortality, at all temperatures tested, at 20 PSU. Only slightly higher mortality was found for 30 PSU at $18^{\circ} \mathrm{C}$ and $24^{\circ} \mathrm{C}$ (Harms, 1986). No such clear trend could be observed in comparison with other experiments (Fig. 2). The overall larval developmental duration to the cypris is shortest in the range 20 to 32 PSU, which corre- 


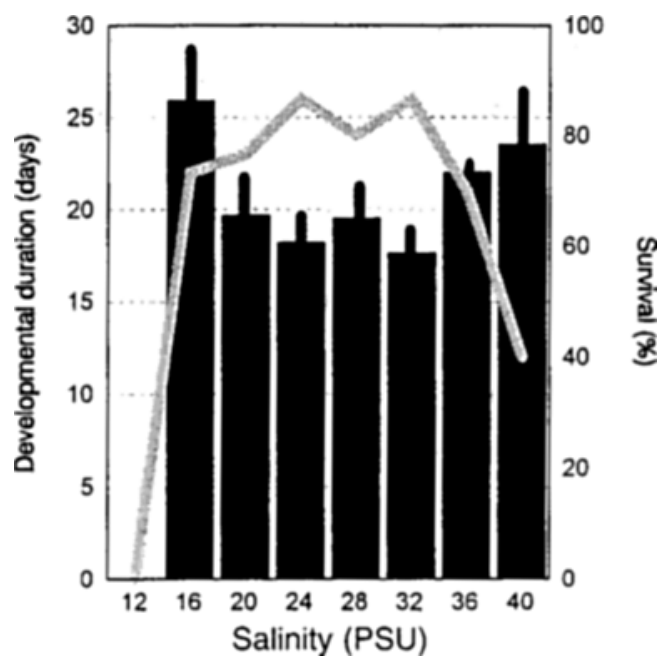

Fig. 2. Effect of salinity on development duration (columns) from hatching to metamorphosis to the cypris stage and development success (line) up to the cypris stage in E. modestus (atter Harms, 1982)

sponds to the range of highest survival. According to these experiments E. modestus larvae are moderately euryhaline.

It is known from experiments by Cawthorne (1978) and Cawthorne \& Davenport (1980) that larvae of $S$. balanoides are less tolerant to changes in salinity than those of E. modestus (Table 1). Differences in salinity tolerance are more pronounced in nauplius stage $I$ than in the cypris. Both species settle in the intertidal and therefore the cypris stage, during which suitable habitats are found for metamorphosis, has to be adapted to at least periodic dilution of seawater. This might be the reason why differences in tolerance levels in the cypris between rapid and slow changes of salinity are less distinct than in the nauplius stage examined.

It was found by Cawthorne \& Davenport (1980) that liberation of larvae ceases at salinities of approximately 21 PSU in E. modestus and at 27 PSU in S. balanoides. Larval development at constant salinity for E. modestus was possible until 16 PSU (Fig. 2), and occasionally even down to $10 \mathrm{PSU}\left(2-6 \%\right.$ at $12^{\circ} \mathrm{C}$ and $18^{\circ} \mathrm{C}$ i see Harms, 1986).

Biomass, respiration rate and food uptake of $E$. modestus were examined for each larval stage at three temperatures $\left(12,18,24^{\circ} \mathrm{C}\right)$ by Harms $(1987)$. Comparable data for S. balanoides, except food uptake, are given by Lucas (1979) and Lucas et al. (1979). The data on dry weight accumulation, weight-specific respiration rate and net growth efficiency $\left(\mathrm{K}_{2}\right)$ are given for both species in Fig. 3. S. balanoides accumulates over three times more biomass during larval development than E. modestus, but in both species weight-specific respiration rate and especially net growth efficiency, which denotes the proportion of assimilated food converted to growth, lay in comparable ranges. The decrease in weight-specific respiration rate indicates that energy reserves, especially glycogen, are accumulated during larval development, to be used later by the nonfeeding cypris stage (Holland \& Walker, 1975). 
Table 1. Effects of salinity decrease (fast and slow) on swimming activity of larval stages of Eliminius modestus and Semibalanus balanoides. Shown are salinity ranges where $50 \%$ of the larvae stopped swimming (according to Cawthorne \& Davenport, 1980)

\begin{tabular}{|lrr|}
\hline Rates of salinity change & $16.74 \mathrm{PSU} / \mathrm{h}$ & 4.81 PSU/h \\
\hline E. modestus, nauplius stage I & $8.8 \pm 0.9 \mathrm{PSU}$ & $6.6 \pm 0.3$ PSU \\
S. balanoides, nauplius stage I & $12.3 \pm 1.0 \mathrm{PSU}$ & $9.3 \pm 1.0 \mathrm{PSU}$ \\
E. modestus, cypris & $9.0 \pm 1.3 \mathrm{PSU}$ & $8.3 \pm 0.9 \mathrm{PSU}$ \\
S. balanoides, cypris & $10.9 \pm 1.0 \mathrm{PSU}$ & $9.1 \pm 1.1 \mathrm{PSU}$ \\
\hline
\end{tabular}

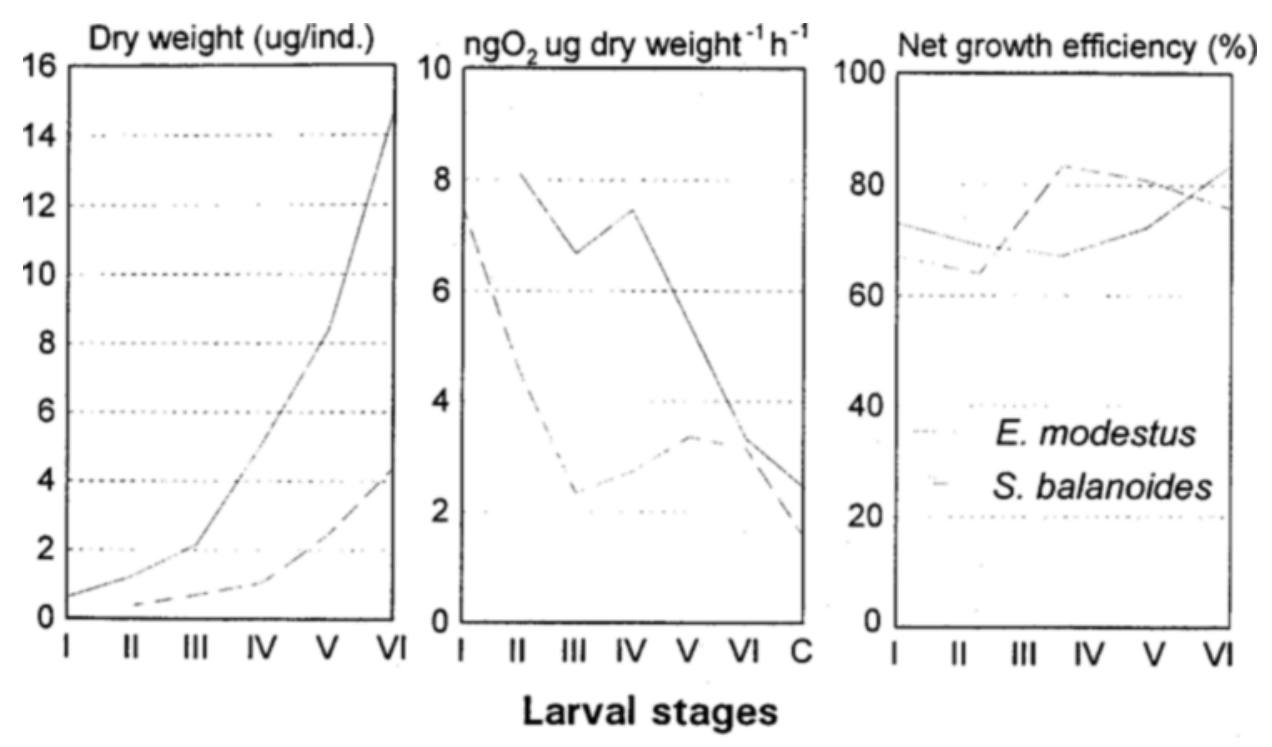

Fig. 3. Growth parameter for larval development of E. modestus and S. balanoides (after Harms, 1987; Lucas, 1979). Shown are weight increment ( $\mu$ g dry weight/ind.) during larval development (nauplius I-VI), weight-specific respiration rate related to dry weight and net growth (ng) efficiency $\left(K_{2}\right)$

\section{Adult behaviour}

Both species settle in the intertidal zone. Hence they encounter rapid fluctuations of physical environmental parameters. Sessile intertidal organisms, like cirripedes, must be able to tolerate severe conditions during emersion. A parameter to describe environmental stress is desiccation, which combines the effect of temperature, humidity and wind speed with the rate of water loss from the integument of organisms.

The influence of desiccation on intertidal zonation in barnacle species was studied in detail by Foster (1971). Figure 4 summarizes the survival times of three barnacle species of various sizes in drying conditions in the intertidal zone. It is obvious that the smaller individuals are more susceptible to drying out. The two intertidal species $E$. 


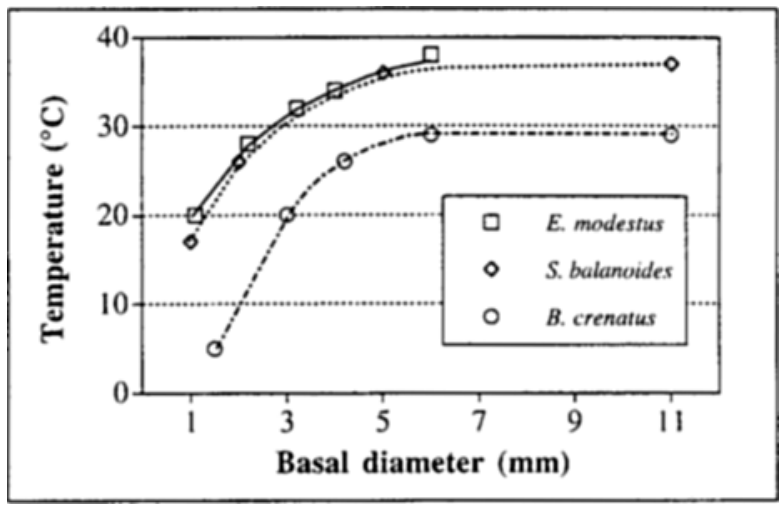

Fig. 4. Temperature influence on desiccation resistance for adult cirripedes of different sizes. Shown are temperature curves at which $50 \%$ of tested individuals died after $6 \mathrm{~h}$ (maximum emersion period during low tide) at zero humidity (Foster, 1971). In all three species tested, desiccation resistance increased with size and was highest in intertidal species

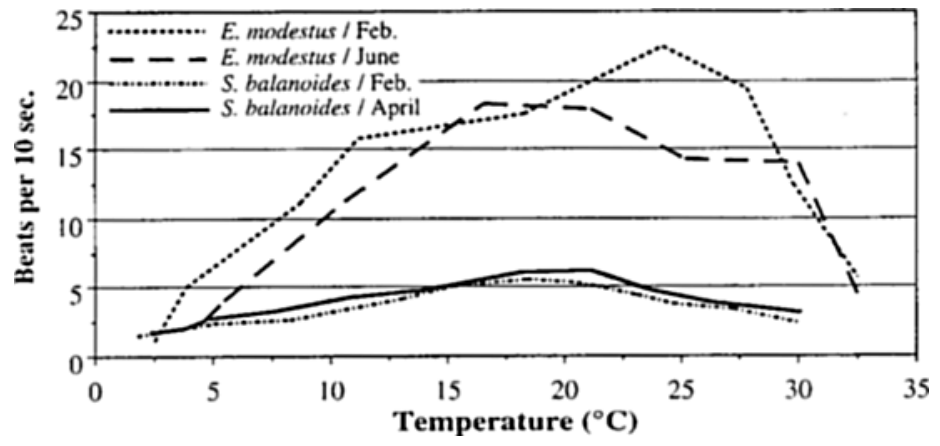

Fig. 5. Cirral activity of adult E. modestus and S. balanoides related to temperature at different seasons (after Southward, 1955a).

modestus and S. balanoides do not show major differences in desiccation resistance. A lower level of tolerance is found in the sublittoral species Balanus crenatus Brugière.

Although Foster (1971) found some evidence that $S$. balanoides may survive slightly longer than E. modestus in similar desiccating conditions at non-lethal temperatures, this is not reflected in the respective intertidal distribution of these two species. E. modestus extends along the European coast to more southern shores compared to the indigenous species $S$. balanoides and reaches slightly higher upper limits in the intertidal, which indicates that $E$. modestus survives better under warmer and, presumably, dryer environmental conditions compared to the indigenous species.

The most obvious activity of a barnacle, and one that plays an important role in both feeding and respiration, is the rhythmic beating of the cirri and the associated movements of the terga and scuta (Crisp \& MacLean, 1990; Crisp \& Southward, 1961; Ritz \& 


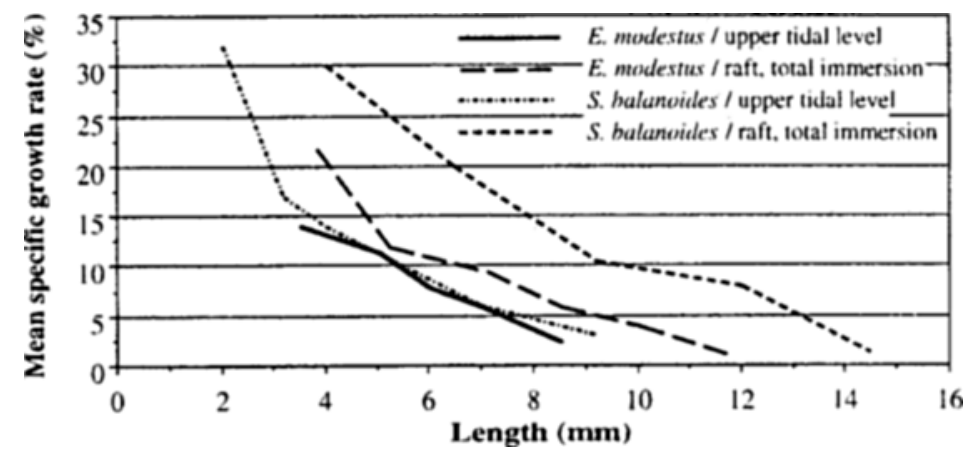

Fig. 6. Mean specific growth rate (percentage increase in length per day) at different tidal levels for juvenile and adult E. modestus and S. balanoides (after Barnes \& Barnes, 1962)

Foster, 1968; Southward, 1955a,b, 1957, 1962, 1964). The most pronounced differences between E. modestus and $S$. balanoides are summarized in Fig. 5.

Southward (1955a) stated in his summary that the immigrant E. modestus was more active at lower temperatures than were the native southern species and at higher temperatures than were the native northern species, and over the whole of its range showed a much greater frequency of cirral beat than any of the native species examined (see Fig. 5).

The consequences of this high cirral activity are shown by an experiment done by Barnes \& Barnes (1962; Fig. 6), who examined the growth rate of E. modestus and $S$. balanoides at different levels of submersion. Populations of the same species were examined, settling in the upper tidal region and on fouling plates hanging from a raft permanently in the water. E. modestus showed much smaller differences in the growth rate between the two habitats than $S$. balanoides. It can be speculated, due to high cirral activity in E. modestus (see Fig. 5), that food intake during a relatively short period of immersion is still adequate to maintain a growth rate close to the one under full immersion.

\section{Fecundity and settling period}

It was calculated by Crisp \& Davies (1955) that assuming a life span of three breeding seasons for E. modestus, an average number of 500 nauplii in each brood, and 12 broods per season the total output of young approaches 20000 per individual. This is equivalent to the output over the same period of three broods of a large specimen of $S$. balanoides, occupying a considerably greater area than one individual of $E$. modestus. The rapid production of numerous broods, as long as water temperatures exceed $6^{\circ} \mathrm{C}$, and the shorter generation time are important features, putting E. modestus at an advantage in its competition with the indigenous $S$. balanoides (Crisp \& Davies, 1955).

The generation time was calculated by Crisp \& Davies (1955) to be about 14 weeks. This is very short compared to that of $S$. balanoides, which is about 1 year. Therefore small eggs produced in successive though smaller broods, which will settle and reach maturity quickly and so contribute to further egg production, mean the euythermal 
species $E$. modestus is at a tremendous advantage over species such as $S$. balanoides (Barnes \& Barnes, 1968).

Related to this successive breeding, larvae of $E$. modestus can be found in plankton throughout most of the year. The settling season of juveniles starts at Heligoland in June and lasts until October (Harms \& Anger, 1983). Assuming that there is always competition for free settling space in benthic communities, this long period of larval abundance increases the chance of finding space to maintain the population. S. balanoides has only one larval release, related to the spring diatom bloom (Barnes, 1962). Spat fall occurs around March and April, in a relatively short period.

It follows from the increase in population density of E. modestus in many areas that there must have been a great increase of nauplii during the summer months. This must have affected the growth of other planktonic larvae. Although this point has already been outlined by Crisp (1958), up to now no detailed studies have been carried out on this subject.

\section{CONCLUSIONS}

As shown by data available in the literature, there are several factors which in total might explain the successful spread of E. modestus throughout the Western European coastal area (Table 2). The larval stages are eurythermal and euryhaline, which enable the larvae to survive in a wide range of habitats. Also, the adults are tolerant of changes in temperature and salinity, but this is less surprising for a sessile intertidal species. The effective utilization of food by high cirral activities in conjunction with the high fecundity over much of the year and the relative short generation time might be the major adaptations responsible for the successful invasion of European waters.

Table 2. Ecological requirements of E. modestus, compared with native species (summarized according to Crisp, 1958). $\mathrm{X}=$ month of the year; LWN = low water nip. LWS = low water spring, HIVN = high water nip, MHW = mean high water, HWS = high water spring; tolerance levels are given from none (-) through low (\#) to high (\#\#\#)

\begin{tabular}{|c|c|c|c|c|c|}
\hline & $\begin{array}{l}\text { Elminius } \\
\text { modestus }\end{array}$ & $\begin{array}{l}\text { Semibala- } \\
\text { nus bala- } \\
\text { noides }\end{array}$ & $\begin{array}{c}\text { Chtha- } \\
\text { malus } \\
\text { stellatus }\end{array}$ & $\begin{array}{l}\text { Balanus } \\
\text { crenatus }\end{array}$ & $\begin{array}{l}\text { Balanus } \\
\text { improvisus }\end{array}$ \\
\hline Season of settlement & $V-X$ & III-IV & VII-IX & IV-IX & $V-I X$ \\
\hline Tidal levels occupied & $\begin{array}{l}\text { MHW, } \\
\text { to below } \\
\text { LWS }\end{array}$ & $\begin{array}{l}\text { HWN } \\
\text { to LWS }\end{array}$ & $\begin{array}{l}\text { HWS } \\
\text { to LWN }\end{array}$ & $\begin{array}{l}\text { Below } \\
\text { LWN }\end{array}$ & $\begin{array}{l}\text { Below } \\
\text { LWN }\end{array}$ \\
\hline Tolerance of low salinity & \#\#\# & \# & - & $\#$ & \#\#\#\# \\
\hline Tolerance of silt & $\# \#$ & \# & $\#$ & $\#$ & $\# \# \#$ \\
\hline $\begin{array}{l}\text { Tolerance of temperature } \\
\left.\qquad<0^{\circ} \mathrm{C}\right)\end{array}$ & \#\# & \#\#\# & \# & \#\# & \#\#革 \\
\hline $\begin{array}{l}\text { Tolerance of temperature } \\
\quad\left(>20^{\circ} \mathrm{C}\right)\end{array}$ & \#\#\# & - & \#\#\#\# & - & \#\# \\
\hline Tolerance of desiccation & $\# \#$ & \#\# & $\# \# \#$ & - & - \\
\hline Resistance to mechanical damage & \# & \#\# & \#\#\#\# & \#\#\# & $\# \#$ \\
\hline Cirral beats at $20^{\circ} \mathrm{C}$ per $10 \mathrm{sec}$ & $17-18$ & $5-6$ & ca. 6 & ca. 10 & ca. 9 \\
\hline
\end{tabular}


Can the results for E. modestus obtained from the European population still be extrapolated to the situation in New Zealand and Australia? Comparison of cirral activity (Ritz \& Foster, 1968) and examination of isoenzymes by gel electrophoresis (Flowerdew, 1984) did not show significant differences between the populations. Only some rare alleles present in the New Zealand population could not be found in the European one. This might be an indication of a relatively small founder population or a later specific selection process. Cultivation experiments at different temperatures and salinities (Harms, 1986) did show differences in larval development and larval size in the two antipodean populations of $E$. modestus. It was suggested that especially extreme winter conditions may act as a kind of natural selection regarding adaptation to lower temperatures in the Northern European population of E. modestus. Up to now it has not been examined whether differences within the European population have been established due to such selection mechanisms.

Acknowledgements. The author is especially gratelul to A. Southward and K. Anger for their helpful comments, which improved the manuscript, and to B. Meyer-Harms for preparation of the figures.

\section{LITERATURE CITED}

Barnes, H., 1962. Note on variations in the release of nauplii of Balanus balanoides with special reference to the spring diatom outburst. - Crustaceand 4, 118-122.

Barnes, H. \& Barnes, M., 1962. The growth rate of Elminius modestus (Crust., Cirripedia) in Scotland. - Int. Rev. Ges. Hydrobiol. 47, 481-486.

Barnes, H. \& Barnes, M., 1968. Egg numbers, metabolic efficiency of egg production and fecundity; local and regiond variations in a number of common cirripedes. - J. Exp. Mar. Biol. Ecol. 2, $135-153$.

Bishop, M. W. H., 1947. Establishment of an immigrant barnacle in British coastal waters. - Nature $159,501-502$.

Bousfield, E. L., 1954. The distribution and spawning season of barnacles on the Atlantic coast of Canada. - Bull. Natl. Mus. Can. 132, 112-154.

Cawthorne, D. F., 1978. Tolerance of some cirrepede nauplii to fluctuating salinities. - Mar. Biol. $46,321-325$.

Cawthorne, D. F. \& Davenport, J., 1980. The effect of fluctuating temperature, salinity, and aerial exposure upon larval release in Balanus balanoides and Elminius modestus. - J. Mar. Biol. Assoc. U.K. $60,367-377$.

Crisp, D. J., 1958. The spread of Elminius modestus Darwin in north-west Europe. - J. Mar. Biol. Assoc. U.K. $37,483-520$.

Crisp, D. J. \& Davies, P. A., 1955. Observations in vivo on the breeding of Elminius modestus grown on glass slides. - J. Mar. Biol. Assoc. U.K. 34, 357-380.

Crisp, D. J. \& MacLean, F. J., 1990. The relation between the dimensions of the cirral net, the beat frequency and the size and age of the animal in Balanus balanoides and E. modestus. - J. Mar. Biol. Assoc. U.K. 70, 505-514.

Crisp, D. J. \& Southward, A. J., 1961. Different types of cirral activity of barnacles. - Philos. Trans. R. Soc. B 243, 271-308.

Flowerdew, M. W., 1984. Electrophoretic comparison of the antipodean cirripede, Elminius modestus, with immigrant European populations. - J. Mar. Biol. Assoc. U.K. 64, 625-635.

Foster, B. A., 1971. Desiccation as a factor in the intertidal zonation of barnacles. - Mar. Biol. 8 , $12-29$.

Harms, J., 1982. Untersuchungen zur Larvalentwicklung und zum Wachstum von Seepocken der Deutschen Bucht. Diplomarbeit, Technische Hochschule Darmstadt, 118 pp. 
Harms, J., 1984. Influence of water temperature on larval development of Elminius modestus and Semibalanus balanoides (Crustacea, Cirripedia). - Helgoländer Meeresunters. 38, 123-134.

Harms, J., 1986. Effects of temperature and salinity on larval development of Elminius modestus (Crustacea, Cirripedia) from Helgoland (North Sea) and New Zealand. - Helgoländer Meeresunters. 40, 355-376.

Harms, J., 1987. Energy budget for the larval development of Elminius modestus (Crustacea: Cirripedia). - Helgoländer Meeresunters. 41, 45-67.

Harms, J. \& Anger, K, 1983. Seasonal, annual, and spatial variation in the development of hard bottom communities. - Hegoländer Meeresunters. 36, 137-150.

Harms, J. \& Anger, K., 1989. Settlement of the barnacle Elminius modestus Darwin on test panels at Helgoland (North Sea): a ten year study. In: Topics in marine biology. Ed. by J. D. Ros Sci. Mar. 53, 417-421.

Holland, D. L. \& Walker, G., 1975. The biochemical composition of the cypris larva of the barnacle Balanus balanoides (L.). - J. Cons. Int. Explor. Mer 36, 162-165.

Hutchins, L. W., 1947. The bases for temperature zonation in geographical distribution. - Ecol. Monogr. 17, 325-335.

King, P. A., Keogh, E. \& McGrath, D., 1997. The current status of the exotic barnacle Elminius modestus Darwin in Galway Bay, Ireland. - Ir. Nat. J. 25, 365-369.

Lucas, M. I., 1979. Studies on energy flow in a barnacle population. Thesis, University of Wales, $257 \mathrm{pp}$.

Lucas, M. I., Walker, G., Holland, D. L. \& Crisp, D. J., 1979. An energy budget for the free-swimming and metamorphosing larvae of Balanus balanoides (Crustacea: Cirripedia). - Mar. Biol. 55, 221-229.

Ritz, D. A. \& Foster, B. A., 1968. Comparison of the temperature responses of barnacles for Britain. south Africa and New Zealand, with special references to temperature acclimation on Elminius modestus. - J. Mar. Biol. Assoc. U. K. 48, 545-558.

Southward, A. J., 1955a. On the behaviour of barnacles. I. The relation of cirral and other activities to temperature. - J. Mar. Biol. Assoc. U.K. 34, 403-422.

Southward, A. J., 1955b. On the behaviour of barnacles. II. The influence of habitat and tidal-level on cirral activity. - J. Mar. Biol. Assoc. U.K. 34, 423-433.

Southward, A. J., 1957. On the behaviour of barnacles. III. Further observations on the influence of temperature and age on cirral activity. - J. Mar. Biol. Assoc. U.K. 36, 323-334

Southward, A. J., 1962. On the behaviour of barnacles. IV. The influence of temperature on cirral activity and survival of some warm water species. - J. Mar. Biol. Assoc. U.K. 42, 163-177.

Southward, A. J., 1964. The relationship between temperature and rhythmic cirral activity in some Cirripedia considered in connection with their geographical distribution. Helgoländer Meeresunters. 10, 391-403.

Southward, A. J., 1991. Forty years of changes in species composition and population density of barnacles on a rocky shore near Plymouth. - J. Mar. Biol. Assoc. U.K. 71, 495-513. 